\title{
PERANCANGAN SARANA PENYELAMAT DIRI DAN KEBUTUHAN APAR PADA DARURAT KEBAKARAN DI KANTOR KESEHATAN PELABUHAN KELAS II BALIKPAPAN
}

\author{
Agus Pratama \\ Kantor Kesehatan Pelabuhan (KKP) Balikpapan \\ Jl. Belitung Darat 118, Belitung Selatan, Kota Banjarmasin, Kalimantan Selatan 70124 \\ Email: agoezt_3887@yahoo.co.id
}

\begin{abstract}
Fire in building could cause human casualties, loss of property, disruption of the activities of the organization, environmental degradation and disturbance of public. In the United State, of 15.300 fire in the rise building are 990 victims and $6,1 \%$ of them fatalities. Therefore fire prevention should be done by implementing the emergency response system wherein fire extinguishing system and means of escape. The purpose of this study was to identify and designing needs portable fire extinguisher and means of escape that have not been fulfilled in building Class II Port Health Office (PHO) of Balikpapan. This research was performed by cross sectional design using observational approach. The interviews performed on 2 officials of Class II PHO of Balikpapan which is considered to know about the condition of the building as object of research. The result of this research are no fire emergency policy and means of escape. In these condition it is provided to the Class II PHO of Balikpapan fixed procedure on fire emergency and evacuation route. Portable fire extinguisher installed as many as 10 units, in accordance with the requirements calculated based Permenakertrans number. 4 1980. Conclusion of this research is Class II PHO of Balikpapan's building has not been having fire emergency policy and adequate means of escape. This condition should see the Class II PHO of Balikpapan create procedure regarding fire emergency and evacuation route.
\end{abstract}

Keywords: fire emergency, means of escape, portable fire extinguisher

\begin{abstract}
ABSTRAK
Kebakaran pada bangunan gedung dapat menimbulkan kerugian berupa korban manusia, harta benda, terganggunya kegiatan organisasi, kerusakan lingkungan dan terganggunya ketenangan masyarakat. Di Amerika, dari 15.300 kebakaran gedung bertingkat terdapat 990 korban dan 6,1\% diantaranya korban meninggal. Maka harus dilakukan upaya pencegahan kebakaran salah satunya dengan menerapkan sistem tanggap darurat yang didalamnya terdapat fasilitas pemadam dan sarana penyelamat diri. Tujuan dari penelitian ini untuk mengindentifikasi dan merancang kebutuhan APAR dan sarana penyelamat diri yang masih belum terpenuhi di gedung Kantor Kesehatan Pelabuhan (KKP) Kelas II Balikpapan. Penelitian ini dilaksanakan dengan rancangan cross sectional dengan menggunakan pendekatan observasional. Wawancara dilaksanakan pada 2 pegawai KKP Kelas II Balikpapan yang dianggap mengetahui mengenai kondisi gedung yang dijadikan objek penelitian. Hasil dari penelitian ini adalah kebijakan darurat kebakaran dan sarana penyelamat diri belum ada. Dalam kondisi tersebut maka diberikan kepada KKP Kelas II Balikpapan mengenai prosedur tetap tentang darurat kebakaran dan jalur evakuasi. APAR yang terpasang sebanyak 10 buah, sesuai dengan kebutuhan yang dihitung berdasarkan Permenakertrans No. 4 tahun 1980. Kesimpulan penelitian ini adalah di gedung KKP Kelas II Balikpapan masih belum memiliki kebijakan darurat kebakaran dan sarana penyelamat diri yang memadai. Melihat kondisi ini sebaiknya KKP Kelas II Balikpapan membuat suatu prosedur standar (SOP) mengenai darurat kebakaran dan jalur evakuasi.
\end{abstract}

Kata kunci: darurat kebakaran, sarana penyelamat diri, APAR

\section{PENDAHULUAN}

Bangunan bertingkat tinggi sangat merebak pembangunannya terutama di kawasan perkotaan, baik sebagai hunian, perkantoran, pusat perbelanjaan maupun tempat rekreasi. Bangunan bertingkat tinggi tentu memiliki jumlah penghuni ataupun pengguna yang tidak sedikit apalagi jika bangunan tersebut berfungsi pula sebagai ruang publik. Dengan demikian keselamatan para penggunanya tentu harus diutamakan dan tidak dapat diabaikan (Indrawan, 2013).

Di berbagai kota besar di Indonesia banyak didirikan bangunan gedung yang merupakan suatu fenomena daerah perkotaan. Faktor keselamatan telah menjadi persyaratan penting yang harus dipenuhi oleh bangunan gedung. Salah satu aspek 
keselamatan adalah keselamatan dari bahaya kebakaran.

Kebakaran pada bangunan gedung dapat menimbulkan kerugian berupa korban manusia, harta benda, terganggunya proses produksi barang dan jasa, kerusakan lingkungan dan terganggunya ketenangan masyarakat (Angela, 2006). Seiring meningkatnya ukuran dan kompleksitas bangunan gedung, sudah seharusnya pula diiringi dengan peningkatan perlindungan terhadap masyarakat. Penanganan kebakaran di gedung-gedung masih mengandalkan kesiapsiagaan dan peralatan dari pemadam kebakaran setempat. Kesiapsiagaan dari pemadam kebakaran gedung pun terkadang masih kurang memadai.

Di Amerika, dari rata-rata 350.000 kali bencana kebakaran di daerah perumahan dan perkantoran yang terjadi dalam setahun, 15.300 kali merupakan kejadian kebakaran di gedung-gedung bertingkat di seluruh Amerika serikat dengan rata-rata 60 orang meninggal, 930 luka-luka dan menelan kerugian sebesar 52 juta dollar mengikuti bencana kebakaran di gedung-gedung bertingkat tersebut. Hasil temuan menyatakan bahwa kebakaran di gedung bertingkat lebih mematikan dan merugikan dibandingkan dengan dari lokasi-lokasi lain di mana bencana kebakaran terjadi. Ditambah lagi penanganan kebakaran di lokasi gedung bertingkat lebih menyulitkan dan berisiko tinggi. Sebuah data dikutip dari National Academy of Sciences US (1986) mencatat bahwa 50\% sampai 80\% kematian karena kebakaran disebabkan oleh racun asap yang keluar dari bencana kebakaran (Indrawan, 2013).

Kebakaran di Indonesia sangat banyak, namun data mengenai angka kebakaran masih sulit ditemukan. Data lengkap sebatas data kebakaran di DKI Jakarta. Menurut Dinas Penanggulangan Kebakaran dan Penyelamatan Provinsi DKI Jakarta pada tahun 2014 terjadi 117 kebakaran dan 5 diantaranya terjadi pada bangunan gedung. Kebakaran tersebut mengakibatkan kerugian material yang tidak sedikit dan bahkan menimbulkan korban jiwa (DKPP Prov. DKI, 2014).

Kebakaran di gedung dapat mengakibatkan kerugian yang tidak sedikit. Tahun 2009 terjadi kebakaran di gedung PT. Kedaung Indah Can (KICI) Surabaya mengakibatkan kerugian mencapai Rp. 20 Miliar (Firdani, 2014). Untuk mengurangi kerugian yang ditimbulkan, maka harus dilakukan upaya pencegahan kebakaran salah satunya dengan menerapkan sistem tanggap darurat. Keadaan darurat adalah situasi atau kondisi kejadian tidak normal yang terjadi tiba-tiba, mengganggu kegiatan, organisasi atau komunikasi dan perlu segera ditanggulangi. Oleh karena itu, keadaan darurat harus segera ditanggulangi agar tidak menghambat proses produksi dan membahayakan pekerja serta lingkungan kerja. Upaya untuk menghindari bertambahnya korban dan kerugian saat terjadi keadaan darurat adalah dengan menerapkan tanggap darurat.

Tanggap darurat kebakaran di gedung bertingkat tidak hanya mengandalkan sistem proteksi aktif seperti alat pemadam ringan (APAR), smoke detector juga springkler, namun diperlukan juga sistem proteksi pasif salah satunya dengan sarana penyelamat diri atau means of escape (MOE). Sarana penyelamat diri sangat penting karena prioritas utama pada saat kebakaran adalah menyelamatkan penghuni atau manusia yang berada di lokasi kejadian. Sebagian besar kematian pada saat terjadi kebakaran di gedung disebabkan oleh asap. Oleh karena itu sangat penting untuk menyiapkan rute aman menyelamatkan diri dari bahaya kebakaran atau asap.

Contoh akibat dari ketiadaan sarana penyelamat diri adalah pada saat terjadi kebakaran gedung Bank Indonesia pada tahun 1997. Gedung tersebut terbakar pada lantai 23 hingga lantai 25 dan mengakibatkan 16 orang meninggal dunia karena terbakar. Hal itu dikarenakan fasilitas pemadam dan sarana penyelamat diri hanya ada hingga lantai 20 dan tidak ada pada lantai di atasnya.

Contoh kebakaran gedung lainnya adalah kebakaran pada Wisma Kosgoro yang terjadi pada tanggal 9 Maret 2015.Gedung yang dibangun pada tahun 1974 itu sebenarnya memiliki fasilitas pemadam, namun tidak terpelihara dengan baik sehingga pada saat terjadi kebakaran alarm kebakaran tidak berbunyi dan springkler tidak mengeluarkan air. Namun sarana penyelamat diri di gedung tersebut dapat menyelamatkan para penghuni yang ada di gedung tersebut sehingga korban jiwa pada kejadian tersebut dapat dihindarkan.

Kantor Kesehatan Pelabuhan Kelas II Balikpapan merupakan unit pelaksana teknis di lingkungan Kementerian Kesehatan yang berada di bawah dan bertanggung jawab kepada Direktorat Jenderal Pengendalian Penyakit dan Penyehatan Lingkungan dan berkedudukan di kota Balikpapan.

Kantor Kesehatan Pelabuhan Kelas II Balikpapan menempati gedung yang berada di jalan Pelita Balikpapan di awal tahun 2013. Gedung berlantai 2 tersebut masih belum memiliki jalur 
evakuasi yang dapat digunakan pada saat darurat kebakaran.

Potensi kebakaran dapat bersumber dari masalah teknis seperti banyaknya bahan yang mudah terbakar di dalam ruangan seperti furniture kantor, alat tulis kantor juga peralatan listrik dan peralatan medis yang ada pada gedung tersebut, instalasi listrik dan juga karena seringnya terjadi pemadaman listrik yang terjadi di kota Balikpapan.

Penerapan sistem tanggap darurat merupakan hal yang penting untuk mengantisipasi adanya keadaan darurat yang disebabkan oleh kebakaran. Penerapan sistem tanggap darurat juga tidak harus menunggu terjadinya keadaan darurat kebakaran namun harus dibuat untuk mengantisipasi adanya kebakaran untuk menciptakan keamanan dan kenyamanan di tempat kerja.

Kantor Kesehatan Pelabuhan Kelas II Balikpapan masih belum memiliki perencanaan sistem manajemen darurat kebakaran. Hal ini dapat mengakibatkan kerugian yang sangat besar pada saat terjadi darurat kebakaran di gedung tersebut. Ditambah lagi belum adanya petugas khusus maupun pegawai yang terampil atau memiliki keahlian di bidang darurat kebakaran.

Tujuan penelitian ini adalah untuk mengindentifikasi dan merancang kebutuhan sarana penyelamat diri dan APAR pada darurat kebakaran di Kantor Kesehatan Pelabuhan Kelas II Balikpapan.

\section{METODE}

Dilihat dari segi analisa data jenis penelitian ini adalah penelitian deskriptif yaitu suatu metode penelitian yang dilakukan dengan tujuan untuk membuat deskripsi atau gambaran tentang suatu keadaan secara objektif. Bila ditinjau dari segi tempat penelitian ini termasuk penelitian lapangan. Sedangkan dari waktu pengumpulan data penelitian ini merupakan penelitian dengan pendekatan cross sectional (Notoatmodjo, 2010).

Populasi pada penelitian ini adalah seluruh karyawan Kantor Kesehatan Pelabuhan Kelas II Balikpapan. Teknik pemilihan responden yang digunakan adalah purposive sampling. Responden ditentukan oleh peneliti yaitu sebanyak 2 orang untuk dilakukan wawancara. Responden tersebut adalah Pimpinan dan Bagian Perencanaan dari kantor tersebut. Pimpinan dipilih karena mengetahui bagaimana kebijakan maupun mengenai sarana penyelamat diri. Bagian perencanaan dipilih sebagai responden karena mengetahui apa saja yang diperlukan oleh Kantor Kesehatan Pelabuhan Kelas II Balikpapan.

Penelitian dilakukan di Kantor Kesehatan Pelabuhan Kelas II Balikpapan. Penelitian dilaksanakan bulan Maret hingga Desember 2015. Pengambilan data dilaksanakan pada bulan September sampai November 2015.

Variabel penelitian dalam penelitian ini adalah kebijakan mengenai darurat kebakaran, sarana penyelamat diri, pintu keluar, koridor/escape routes, tangga darurat, petunjuk arah/exit sign, titik kumpul/ muster point dan APAR yang ada di gedung Kantor Kesehatan Pelabuhan Kelas II Balikpapan.

Kebijakan mengenai darurat kebakaran adalah panduan mutu atau manual mutu yang digunakan sebagai pedoman pada saat terjadi darurat kebakaran. Kebijakan bencana kebakaran pada gedung salah satunya adalah menentukan jalur penyelamatan keluar dari gedung (Hadhiatma, 2015).

Sarana penyelamat diri yaitu sarana gedung yang pada saat keadaan darurat kebakaran dapat digunakan oleh penghuni untuk menyelamatkan diri dengan keluar dari gedung. Sarana penyelamat diri ini dibagi menjadi tiga bagian, yaitu jalur evakuasi (pintu darurat, koridor dan tangga darurat), tanda arah keluar/exit sign dan titik kumpul/muster point.

Pintu darurat adalah pintu yang dapat digunakan bila terjadi keadaan darurat. Menurut Ramli (2010), kriteria pintu darurat dapat dihitung berdasarkan rumus berikut: kriteria pintu keluar menurut Ramli (2010):

Lebar Pintu

$U=\frac{N}{40 \times T}$

Di mana

N: Jumlah Orang

T: Batas/waktu dalam menit (3', 2.5', 2')

U: Banyaknya LTK yang dibutuhkan

Jumlah Pintu

$E=\frac{U}{4}+1$

Di mana

E: Banyaknya tempat keluar.

Koridor/escape routes adalah jalur-jalur aman yang ditetapkan untuk menuju ke titik kumpul pada saat terjadi keadaan darurat. Kriteria koridor menurut Ramli (2010): tidak licin, bebas hambatan, lamanya waktu keluar (risiko ringan $=3$ menit, risiko sedang $=2,5$ menit dan risiko berat $=2$ menit) dan panjang 
jarak tempuh (risiko ringan $=30$ meter, risiko sedang $=20$ meter dan risiko berat $=15$ meter).

Tangga darurat adalah tangga yang dapat digunakan pada saat terjadi keadaan darurat. Kriteria tangga darurat SNI 03-1746-2000, antara lain: lebar bersih $110 \mathrm{~cm}$ (44 inci) atau $90 \mathrm{~cm}$ (36 inci) bila penghuni yang dilayani jalur tangga kurang dari 50 orang, maksimum ketinggian anak tangga $19 \mathrm{~cm}$ (7,5 inci), kedalaman anak tangga minimum $25 \mathrm{~cm}$ (10 inci) dan tinggi ruang minimum $200 \mathrm{~cm} \mathrm{(6ft,} 8$ inci).

Petunjuk arah/exit sign adalah tanda menuju arah keluar atau evakuasi. Kriteria petunjuk arah menurut SNI 03-6574-2001, antara lain: lokasi pemasangan (arah menuju tempat aman dan di lokasi yang mudah terbaca, pada setiap pintu menuju tangga yang aman setinggi $15 \mathrm{~cm}-20 \mathrm{~cm}$ dari dasar tanda ke lantai dengan tulisan "EXIT", dipasang pada pintu darurat dengan jarak $10 \mathrm{~cm}$ dari rangka pintu dan tidak ada dekorasi atau perabotan yang menghalangi tanda tersebut), ukuran exit sign (tanda "EXIT" diberi warna kontras dengan latar belakang, tanda "EXIT" ditulis dengan huruf kapital dengan tinggi minimal $15 \mathrm{~cm}$, tebal minimal $2 \mathrm{~cm}$, lebar minimal $5 \mathrm{~cm}$ dan jarak minimum antar huruf $1 \mathrm{~cm}$ ) dan pencahayaan 300 lux dalam keadaan normal dan 10 lux dalam keadaan darurat.

Titik kumpul/muster point adalah area berkumpul pada saat terjadi keadaan darurat. Kriteria titik kumpul (NFPA 101 tahun 2000), antara lain: menyediakan space $0,3 \mathrm{~m}^{2}$ per satu orang dengan tinggi minimal $200 \mathrm{~cm}$ atau lebih, berjarak 6,1 meter dan aman dari jatuhan dan bahaya lainnya, lokasinya memiliki akses menuju tempat yang lebih aman dan tidak menghalangi kendaraan penanggulangan keadaan bahaya.

APAR adalah alat pemadam ringan yang bisa dioperasikan oleh satu orang. Kriteria APAR menurut Permenakertrans No. 4 tahun 1980: jenis APAR (Air, Busa, Serbuk kimia Kering, Karbon Dioksida atau Halon), konstruksi APAR (tabung gas atau tabung bertekanan tetap), rating APAR (Kelas A, B, C atau D), ukuran APAR dan terdapat tanda APAR yang dipasang $125 \mathrm{~cm}$ dari lantai, berbentuk segitiga, berwarna merah dengan tulisan putih yang terlihat jelas.

Jumlah kebutuhan APAR dihitung berdasarkan dengan luas bangunan sesuai dengan luas coverage APAR dari NFPA 10 tahun 2002.

Teknik pengumpulan data dalam penelitian ini didapatkan dengan cara mengumpulkan data primer melalui observasi, wawancara dan pengukuran, kemudian data sekunder dengan mengumpulkan data mengenai prosedur tanggap darurat yang telah ditetapkan dan foto-foto hasil observasi seperti foto exit sign dan muster point.

Data yang diperoleh akan diolah dan dianalisis secara deskriptif, kemudian hasilnya akan disajikan dalam bentuk narasi. Pengolahan dan analisis data akan dihubungkan dengan teori yang terkait dengan sistem tanggap darurat sehingga peneliti dapat mengindentifikasi fasilitas sarana penyelamat diri dan merancang sistem tanggap darurat kebakaran di Kantor Kesehatan Pelabuhan Kelas II Balikpapan.

\section{HASIL}

Hasil dari wawancara yang dilakukan peneliti kepada 2 responden didapatkan hasil bahwa Kantor Kesehatan Pelabuhan Kelas II Balikpapan masih belum memiliki kebijakan mengenai darurat kebakaran dan diketahui pula Kantor Kesehatan Pelabuhan Kelas II Balikpapan masih belum dilengkapi dengan sarana penyelamat diri yang memadai.

Kebijakan merupakan pedoman dan dasar rencana dalam melaksanakan suatu pekerjaan. Kebijakan penanggulangan darurat kebakaran disusun agar pada saat terjadi darurat kebakaran masing-masing perorangan dapat mengetahui apa saja yang harus dilakukan sesuai dengan kebijakan yang dibuat. Kantor Kesehatan Pelabuhan Kelas II Balikpapan merupakan unit pelayanan teknis di bawah Kementerian Kesehatan yang melayani masyarakat umum yang ingin mendapatkan pelayanan kesehatan. Namun Kantor Kesehatan Pelabuhan Kelas II Balikpapan masih belum memiliki peraturan maupun kebijakan mengenai darurat kebakaran. Kebijakan mengenai darurat kebakaran yang masih belum ada di Kantor Kesehatan Pelabuhan Kelas II Balikpapan menandakan bahwa kantor tersebut belum menerapkan sistem penanggulangan darurat kebakaran.

Fasilitas penunjang pada darurat kebakaran seperti sarana penyelamat diri diperlukan setiap gedung, terutama di gedung bertingkat dan berpenghuni. Di gedung Kantor Kesehatan Pelabuhan Kelas II Balikpapan sendiri sedang melengkapi fasilitas darurat kebakaran tersebut. Belum ada jalur evakuasi yang ditentukan pada gedung Kantor Kesehatan Pelabuhan Kelas II Balikpapan. Demikian pula sign atau tanda yang menunjukkan jalur evakuasi. Terdapat sign di dekat 
tangga yang menunjukkan arah menurun dan sign titik kumpul yang menunjukkan area titik berkumpul di depan pos satpam.

Observasi dan pengukuran di lakukan pada sarana penyelamat diri maupun pendukungnya seperti koridor, tangga, pintu keluar, petunjuk arah, titik kumpul dan APAR.

\section{Koridor}

Koridor terdapat di lantai 1 maupun lantai 2 dengan lebar 2 meter. Panjang koridor di lantai 1 sepanjang 39 meter dihitung dari pintu belakang gedung hingga pintu depan gedung. Panjang koridor lantai 2 sepanjang 32 meter dihitung dari jendela belakang hingga depan ruang rapat. Terdapat pintu yang berada di tengah koridor lantai 1 yang dapat menjadi halangan.

\section{Tangga}

Terdapat 2 buah tangga yang berada di tengah gedung dan belakang gedung. Tangga tengah memiliki lebar $130 \mathrm{~cm}$ dihitung antara rel pegangan. Tangga belakang memiliki lebar $95 \mathrm{~cm}$ dihitung dari dinding hingga rel pegangan tangga. Kedua tangga tersebut memiliki kedalaman anak tangga $30 \mathrm{~cm}$ dan ketinggian anak tangga sebesar 18,5 $\mathrm{cm}$. Tinggi ruang pada tangga setinggi $400 \mathrm{~cm}$. Gedung ini tidak memiliki tangga darurat khusus yang memiliki kompartemen sendiri maupun yang ada di luar gedung.

\section{Pintu Keluar}

Gedung Kantor Kesehatan Pelabuhan Kelas II Balikpapan memiliki 3 pintu keluar yang berada di lantai 1 gedung. Pintu tersebut digunakan juga sebagai pintu masuk. Pintu pertama ada di depan gedung dengan lebar bukaan 1,6 meter dan tinggi 2,1 meter, konstruksi kaca dilengkapi dengan sensor automatic. Jarak pintu dengan titik kumpul adalah 10 meter. Pintu kedua berada di sebelah kanan gedung dengan lebar bukaan 1,6 meter dan tinggi 2,1 meter, bahan pintu terbuat dari alumunium dan kaca. Jarak pintu dengan titik kumpul sebesar 26 meter. Pintu ketiga berada di belakang gedung dengan lebar bukaan 1,6 meter dan tinggi 2,1 meter, bahan pintu terbuat dari alumunium dan kaca. Jarak pintu dengan titik kumpul sebesar 45 meter.

\section{Titik Kumpul}

Titik kumpul berada di depan gedung Kantor Kesehatan Pelabuhan Kelas II Balikpapan. Tersedia ruang sebesar $150 \mathrm{~m}^{2}$ yang dapat digunakan sebagai tempat berkumpul saat terjadi darurat kebakaran. Titik kumpul tersebut juga digunakan pengurus untuk digunakan sebagai parkir kendaraan pegawai maupun pengunjung.

\section{Alat pemadam api ringan (APAR)}

APAR yang ada di Kantor Kesehatan Pelabuhan Kelas II Balikpapan sudah terpasang sejak bulan agustus 2015 sebanyak 10 buah. APAR tersebut berisi gas halotron yang merupakan turunan dari gas halon dan memiliki kapasitas $6 \mathrm{~kg}$. Material tabung APAR tersebut terbuat dari bahan mild steel dan dilapisi dengan cat berwarna merah. Rating/kelas kebakaran yang dapat ditanggulangi yaitu kelas A, B dan C hingga 12.000 volt. Pemasangan APAR telah dilengkapi dengan tanda dan tinggi pemasangan tanda $125 \mathrm{~cm}$ dari permukaan lantai.

Tanda pemasangan berbentuk kotak berukuran $30 \times 25 \mathrm{~cm}$, berwarna merah, terdapat tulisan "TABUNG PEMADAM API" berwarna merah dengan tinggi huruf $5 \mathrm{~cm}$ dan petunjuk arah berwana putih dengan tinggi $7,5 \mathrm{~cm}$. Tabung APAR di pasang $10 \mathrm{~cm}$ di bawah tanda tersebut.

APAR yang ada di Kantor Kesehatan Pelabuhan kelas II Balikpapan adalah sebanyak 10 buah, 5 buah APAR dipasang di lantai 1 gedung dan 5 buah APAR lainnya dipasang di lantai 2 gedung. APAR lantai 1 diletakkan di samping pintu utama gedung, depan ruang arsip, di dalam ruang arsip, di dalam ruang klinik, dan di depan ruang VCT. APAR lantai 2 diletakkan di depan ruang rapat, depan ruang kepegawaian, depan ruang tata usaha, depan suang Seksi PKSE, dan depan ruang Seksi UKLW.

\section{PEMBAHASAN}

\section{Kebijakan Darurat Kebakaran}

Kepmenaker RI No. KEP.186/MEN/1999 mengatakan bahwa setiap pengurus atau manajemen suatu organisasi diwajibkan mencegah atau mengurangi kebakaran di tempat kerja. Salah satu kewajiban ini adalah membuat buku rencana penanggulangan darurat kebakaran atau sebuah standar operasional prosedur tentang penanggulangan darurat kebakaran.

Kantor Kesehatan Pelabuhan Kelas II Balikpapan masih belum memiliki sebuah panduan mutu atau manual mutu mengenai penanggulangan kebakaran. Hal tersebut dapat diartikan bahwa Kantor Kesehatan Pelabuhan Kelas II masih 
belum memiliki suatu sistem penanggulangan darurat kebakaran. Seharusnya menurut ketentuan Kepmenaker diatas Kantor Kesehatan Pelabuhan Kelas II Balikpapan sudah memiliki panduan mutu atau manual mutu mengenai penanggulangan kebakaran, karena penghuni yang ada di gedung Kantor Kesehatan Pelabuhan Kelas II Balikpapan lebih dari 50 orang sesuai Keputusan Menteri Tenaga Kerja Republik Indonesia No. 186 tahun 1999 pasal 2 butir 2 .

Usulan mengenai standar operasional prosedur (SOP) tentang penanggulangan darurat kebakaran diberikan untuk memenuhi peraturan dari Kepmenaker No. 186 tahun 1999 tersebut. Tujuan dibuatnya SOP ini adalah untuk mengetahui tindakan yang diperlukan jika terjadi darurat kebakaran dan untuk mengetahui peran dan fungsi tiap-tiap petugas atau orang yang diberikan tanggung jawab pada saat terjadi darurat kebakaran dan memperjelas alur tugas, wewenang dan tanggung jawab petugas yang terkait. Usulan SOP tentang penanggulangan darurat kebakaran dapat dilihat di lembar lampiran.

\section{Fasilitas Penyelamat Diri dan Pemadam}

Menurut Permen PU No. 26 Tahun 2008 dikatakan bahwa setiap orang atau badan hukum termasuk instansi Pemerintah Pusat dan Pemerintah Daerah dalam penyelenggaraan pembangunan bangunan gedung wajib memenuhi persyaratan teknis yang diatur dalam peraturan pelaksanaan sistem proteksi kebakaran pada bangunan gedung dan lingkungan. Diantara persyaratan teknis tersebut terdapat persyaratan mengenai proteksi kebakaran aktif dan pasif yang harus dipenuhi.

Hasil observasi yang telah dilakukan di gedung Kantor Kesehatan Pelabuhan Kelas II Balikpapan, sarana penyelamat diri di gedung Kantor Kesehatan Pelabuhan Kelas II Balikpapan juga masih belum lengkap. Gedung tersebut masih belum menentukan jalur evakuasi yang digunakan apabila terjadi darurat kebakaran, demikian pula tanda atau sign jalur evakuasi. Kantor Kesehatan Pelabuhan Kelas II Balikpapan sudah menentukan di mana letak titik berkumpul atau muster point dan melengkapinya dengan tanda. Berikut adalah tabel hasil observasi pada sarana penyelamat diri yang ada di gedung Kantor Kesehatan Pelabuhan Kelas II Balikpapan.

Fasilitas sarana penyelamat diri di Kantor Kesehatan Pelabuhan Kelas II Balikpapan masih banyak yang belum tersedia (Tabel 1), seperti tidak terdapat jalur evakuasi di kedua lantai, tidak memiliki exit sign yang digunakan untuk memandu penghuni keluar gedung dengan aman. Tangga darurat juga tidak tersedia, namun dapat digantikan dengan tangga yang sudah ada di gedung tersebut.

Sarana penyelamat diri yang belum lengkap tersebut tidak memenuhi persyaratan teknis yang tertera dalam ketentuan teknis PermenPU No. 26 Tahun 2008 pada Bab III. Dalam ketentuan tersebut bangunan gedung seharusnya memiliki sarana penyelamat diri yang terdiri dari penentuan jalur evakuasi (koridor, pintu dan tangga), tanda arah dan titik berkumpul. Oleh karena itu, diberikan usulan mengenai sarana penyelamat diri untuk memenuhi persyaratan teknis gedung menurut Permen PU No. 26 Tahun 2008.

Fasilitas pemadam yang ada di gedung tersebut sudah dilengkapi dengan APAR sebanyak 10 buah yang berisi gas halotron. Namun untuk mengetahui apakah efektif atau tidak digunakan pada gedung tersebut akan dijelaskan pada pembahasan mengenai APAR.

Berdasarkan hasil observasi tersebut dapat dikatakan bahwa Kantor Kesehatan Pelabuhan Kelas II Balikpapan masih belum melaksanakan ketentuan dari Permen PU No. 26 Tahun 2008, karena masih ada sarana proteksi yang masih belum lengkap atau memenuhi syarat.

\section{Rute Penyelamat (Exit Route)}

Dilihat dari bangunan gedung, tipe penyelamatan diri yang dapat digunakan di gedung Kantor Kesehatan Pelabuhan Kelas

II Balikpapan untuk melarikan diri dari bahaya kebakaran adalah dengan melalui koridor sebelum menuju tempat terbuka. Namun rute atau jalur penyelamatan tersebut masih belum ditentukan.

Menentukan rute penyelamat diri harus memenuhi persyaratan yang memungkinkan penghuni dapat menyelamatkan diri dengan cepat

Tabel 1. Evaluasi Sarana Penyelamat Diri

\begin{tabular}{crllll}
\hline Lantai & Exit Route & \multicolumn{1}{c}{ Exit Door } & Tangga Darurat & Exit Sign & \multicolumn{1}{c}{ Titik Kumpul } \\
\hline 1 & Tidak Tersedia & Tersedia & Tidak Diperlukan & Tidak Tersedia & Tersedia \\
2 & Tidak Tersedia & Tidak Diperlukan & Tidak Tersedia & Tidak Tersedia & Tidak Diperlukan \\
\hline
\end{tabular}


dan aman. Persyaratan itu adalah setiap rute penyelamat dibuat permanen dengan material tahan api, tinggi minimum 2,3 meter, lebar minimum 0,71 meter dan harus bersih dari segala halangan. Selain persyaratan tersebut perlu juga diperhatikan risiko bahaya hunian, jumlah penghuni, juga panjang koridor yang akan dilewati. Risiko bahaya hunian gedung Kantor Kesehatan Pelabuhan Kelas II Balikpapan adalah risiko ringan.

\section{Koridor}

Gedung yang memiliki risiko bahaya kebakaran ringan seperti gedung Kantor Kesehatan Pelabuhan Kelas II Balikpapan dibutuhkan lama waktu untuk sampai keluar gedung maksimal adalah 3 menit dengan panjang jarak tempuh maksimal 30 meter.

Di lantai 1 gedung terdapat koridor sepanjang 39 meter dan lantai 2 sepanjang 32 meter. Dapat dipastikan untuk menempuh pintu keluar, sebagian penghuni menempuh jarak lebih dari 30 meter. Hal ini tidak sesuai dengan ketentuan yang berlaku.

Lebar koridor di lantai 1 maupun lantai 2 sudah cukup lebar yaitu sepanjang 2 meter. Pengahalang yang ada di lantai 1 berupa pintu dapat menghambat penghuni untuk menuju pintu keluar, maka dari itu pintu harus selalu terbuka pada saat terdapat penghuni di gedung tersebut.

\section{Pintu Keluar}

Pintu keluar yang tersedia di gedung Kantor Kesehatan Pelabuhan Kelas II Balikpapan sebanyak 3 buah dan tidak ada pintu khusus yang digunakan pada saat terjadi darurat kebakaran, namun tidak semuanya dapat dijadikan pintu keluar saat terjadinya darurat kebakaran. Perlu diperhitungkan dengan memperhatikan banyaknya penghuni dan pintu mana yang terdekat dengan titik kumpul.

Tabel 2. Perbandingan Kriteria Tangga dengan Persyaratan SNI 03-1746-2000.

\begin{tabular}{llcc}
\hline \multicolumn{1}{c}{ Kriteria } & SNI 03-1746-2000 & $\begin{array}{c}\text { Tangga } \\
\mathbf{1}\end{array}$ & $\begin{array}{c}\text { Tangga } \\
\mathbf{2}\end{array}$ \\
\hline Lebar & $\begin{array}{l}110 \mathrm{~cm} \text { atau } 90 \mathrm{~cm} \\
\text { (bila penghuni }<90)\end{array}$ & $130 \mathrm{~cm}$ & $95 \mathrm{~cm}$ \\
Ketinggian & Maksimum $19 \mathrm{~cm}$ & $18,5 \mathrm{~cm}$ & $18,5 \mathrm{~cm}$ \\
$\begin{array}{l}\text { anak tangga } \\
\text { Kedalaman } \\
\text { anak tangga }\end{array}$ & Minimum $10 \mathrm{~cm}$ & & \\
Tinggi ruang & Minimum $200 \mathrm{~cm}$ & $30 \mathrm{~cm}$ & $30 \mathrm{~cm}$ \\
\hline
\end{tabular}

Setelah melakukan perhitungan didapatkan kebutuhan pintu darurat untuk digunakan di gedung Kantor Kesehatan Pelabuhan Kelas II Balikpapan sebanyak 2 buah dengan lebar pintu sebesar $52,5 \mathrm{~cm}$.

\section{Tangga}

Gedung Kantor Kesehatan Pelabuhan Kelas II Balikpapan tidak memiliki tangga darurat khusus yang sesuai persyaratan SNI 03-1746-2000.Terdapat pengecualian untuk tangga yang sudah ada dengan memenuhi persyaratan. Untuk menentukan apakah tangga yang ada di gedung Kantor Kesehatan Pelabuhan Kelas II Balikpapan dapat digunakan pada saat darurat kebakaran maka dapat dilihat perbandingan kriteria tangga yang ada dengan persyaratan SNI 03-1746-2000 pada Tabel 2. Dari perbandingan pada Tabel 2, kedua tangga yang ada di gedung Kantor Kesehatan Pelabuhan Kelas II Balikpapan dapat digunakan sebagai pengganti tangga darurat dan digunakan pada saat terjadi darurat kebakaran.

\section{Jalur Evakuasi}

Jalur evakuasi di gedung Kantor Kesehatan Pelabuhan Kelas II Balikpapan masih belum ada untuk itu diberikan usulan jalur evakuasi untuk gedung Kantor Kesehatan Pelabuhan Kelas II Balikpapan sesuai dengan keadaan yang ada dan pada pembahasan sebelumnya. Usulan jalur evakuasi untuk lantai 1 dan lantai 2 akan dijelaskan lebih lanjut.

Jalur evakuasi di lantai 1, sebagian penghuni diarahkan menuju ke pintu depan gedung dan sebagian penghuni diarahkan pintu tengah gedung menuju titik kumpul yang telah ditentukan. Terdapat pintu ditengah gedung yang dapat menjadi penghalang jalur evakuasi. Pintu tersebut harus selalu terbuka apabila terdapat penghuni di gedung tersebut.

Jalur evakuasi lantai 2 dibagi menjadi 2 jalur sesuai dengan letak tangga yang ada di gedung Kantor Kesehatan Pelabuhan Kelas II Balikpapan. Jalur evakuasi tersebut dibatasi oleh pintu yang terdapat di tengah gedung. Untuk ruang Kepala Kantor, ruang rapat, ruang kepegawaian dan sebagian penghuni ruang tata usaha yang keluar melalui pintu ruang bagian depan dapat turun melalui tangga utama yang terletak di depan. Sedangkan ruang yang lain dan sebagian penghuni ruang tata usaha yang keluar ruangan melalui pintu bagian belakang dapat 
turun melalui tangga yang terletak di depan ruang seksi PKSE.

\section{Titik Kumpul}

Titik kumpul berada di lahan parkir pengunjung yang berada di depan gedung Kantor Kesehatan Pelabuhan Kelas II Balikpapan. Berdasarkan kriteria titik kumpul, titik kumpul tersebut sudah memenuhi semua persyaratan seperti jarak titik kumpul dengan gedung sejauh 10 meter, dapat mengakomodasi seluruh penghuni yang berjumlah kurang lebih 91 orang dengan luas $150 \mathrm{~m}^{2}$, dan tidak menghalangi kendaraan penganggulangan bahaya kebakaran apabila terjadi darurat kebakaran di gedung Kantor Kesehatan Pelabuhan Kelas II Balikpapan.

Titik kumpul yang ada di Kantor Kesehatan Pelabuhan Kelas II Balikpapan sudah memenuhi semua persyaratan NFPA 101 tahun 2000, namun dikarenakan terletak bersamaan dengan letak parkir kendaraan pengunjung hal ini dapat menjadi penghalang penghuni menuju ke titik kumpul yang telah ditentukan. Maka sebaiknya manajemen Kantor Kesehatan Pelabuhan Kelas II Balikpapan dapat menentukan atau menata ulang tempat parkir atau titik kumpul sehingga tidak menjadi satu.

\section{Petunjuk Arah (Exit Sign)}

Berdasarkan hasil observasi yang telah dilakukan di Kantor Kesehatan Pelabuhan Kelas II Balikpapan masih belum melengkapi petunjuk arah yang diperlukan untuk melengkapi sarana penyelamat diri pada darurat kebakaran.

Menurut SNI 03-6574-2001, exit sign diletakkan pada tempat-tempat yang telah dipersiapkan sebagai petunjuk sarana penyelamatan diri ketika terjadi sebuah bencana, seperti pintu darurat, jalur evakuasi, tangga darurat dan titik kumpul. Berikut tata cara pemasangan petunjuk arah: pada lokasi pemasangan sign arah menuju tempat aman dan di lokasi yang mudah terbaca, pada setiap pintu menuju tangga yang aman setinggi $15 \mathrm{~cm}-20 \mathrm{~cm}$ dari dasar tanda ke lantai dengan tulisan "EXIT", dipasang pada pintu darurat dengan jarak $10 \mathrm{~cm}$ dari atas rangka pintu, tidak ada dekorasi atau perabotan yang menghalangi tanda tersebut, pencahayaan 300 lux dalam keadaan normal dan 10 lux dalam keadaan darurat dan dibuat dari bahan yang dapat memantulkan cahaya (reflecting) atau dibuat dari bahan yang dapat menyimpan cahaya (photoluminous) agar terlihat pada saat gelap. Ukuran exit sign yaitu: tanda "EXIT" diberi warna kontras dengan latar belakang dan tanda "EXIT" ditulis dengan huruf kapital dengan tinggi minimal $15 \mathrm{~cm}$, tebal minimal $2 \mathrm{~cm}$, lebar minimal $5 \mathrm{~cm}$ dan jarak minimum antar huruf $1 \mathrm{~cm}$.

Berdasarkan pembahasan diatas diberikan usulan penempatan petunjuk arah untuk gedung Kantor Kesehatan Pelabuhan Kelas II Balikpapan. Usulan penempatan petunjuk arah akan dijelaskan lebih lanjut.

Penempatan petunjuk arah di lantai 1, petunjuk arah yang dibutuhkan sebanyak 7 buah. Petunjuk arah diletakkan di pintu depan yang menjadi pintu keluar gedung, depan tangga utama dan belakang, depan ruang arsip, tembok belakang tangga, depan pintu tengah gedung dan di tiang tembok depan ruang laboratorium klinik. Petunjuk arah yang di letakkan di pintu depan dipasang $10 \mathrm{~cm}$ diatas rangka pintu. Petunjuk arah yang diletakkan di depan pintu tengah gedung dipasang menggantung pada plafon gedung.

Untuk penempatan petunjuk arah di lantai 2, petunjuk arah yang dibutuhkan sebanyak 4 buah. Petunjuk arah diletakkan di depan ruang rapat, dinding tangga utama, tiang tembok depan ruang tata usaha dan dipasang menggantung depan tangga belakang.

\section{APAR}

Menentukan risiko kebakaran dan klasifikasi bahaya kebakaran di setiap ruangan gedung Kantor Kesehatan Pelabuhan Kelas II Balikpapan harus dilakukan sebelum membahas kebutuhan alat pemadam api ringan (APAR). Tujuan bahasan ini adalah untuk menentukan jenis APAR yang efektif digunakan pada gedung Kantor Kesehatan Pelabuhan Kelas II Balikpapan. Untuk mempermudah penggunaan dan menjaga kualitas APAR tersebut perlu dilakukan pemasangan dan pemeliharaan yang sesuai dengan peraturan tentang syarat pemasangan dan pemeliharaan APAR yaitu Permenakertrans no. 4 Tahun 1980 (Isnaini, 2009).

Klasifikasi bahaya hunian menurut SNI 033989-2000, Kantor Kesehatan Pelabuhan Kelas II Balikpapan termasuk memiliki risiko bahaya kebakaran ringan karena masuk pada kelompok perkantoran dan tempat perawatan. Dari hasil observasi yang telah dilakukan, dapat disimpulkan bahwa klasifikasi atau kelas bahaya kebakaran untuk Kantor Kesehatan Pelabuhan Kelas II Balikpapan adalah kelas A, B dan C.

Lantai 1 gedung terdapat 7 ruangan yang memiliki kelas bahaya kebakaran A dan C, karena ruangan tersebut terdapat bahan padat yang mudah 
terbakar seperti kertas, meja kayu dan kursi selain itu juga terdapat peralatan elektronik yang berisiko terjadi kebakaran yang dikarenakan arus listrik. 6 ruang berikutnya memiliki kelas bahaya kebakaran $\mathrm{A}, \mathrm{B}$ dan $\mathrm{C}$ dikarenakan selain terdapat benda padat dan peralatan elektronik yang berisiko terjadi kebakaran terdapat pula cairan kimia maupun gas yang mudah terbakar seperti alkohol dan tabung berisi oksigen yang terdapat di laboratorium dan tempat penyimpanan obat, solar yang berada di gudang pestisida dan di area genset, serta terdapat tabung berisi LPG di dapur.

Lantai 2 gedung memiliki risiko kebakaran A dan $C$, karena di lantai 2 hanya terdapat benda padat berupa alat tulis, perlengkapan kantor dan peralatan elektronik yang mengandung listrik.

Rancangan kebutuhan APAR dibuat berdasarkan Permenakertrans No. 4 tahun 1980. Berdasarkan hasil pembahasan mengenai risiko kebakaran pada gedung Kantor Kesehatan Pelabuhan Kelas II Balikpapan didapatkan hasil bahwa gedung tersebut memiliki risiko kebakaran ringan dengan kelas kebakaran A, B dan C. Jenis APAR yang paling efektif untuk kelas kebakaran tersebut adalah APAR berisi serbuk kimia kering (tepung).

Total kebutuhan APAR untuk gedung Kantor Kesehatan Pelabuhan Kelas II Balikpapan adalah 10 buah dengan Rating 1A dan berjenis serbuk kimia kering (tepung). Jarak maksimal antar APAR dalam pemasangannya menurut Permenakertrans No. 4 tahun 1980 adalah 15 meter.

APAR yang sudah ada di Kantor Kesehatan Pelabuhan Kelas II Balikpapan berjumlah 10 buah dan berisi gas Halotron dengan berat $6 \mathrm{~kg}$. Jumlah APAR sudah sesuai dengan kebutuhan APAR yang dihitung berdasarkan Permenakertrans No. 4 Tahun 1980.

APAR yang dimiliki Kantor Kesehatan Pelabuhan Kelas II Balikpapan berisi gas Halotron. Gas halotron merupakan turunan gas halon yang aman untuk lingkungan dan tidak mengandung CFC yang dilarang oleh pemerintah (clean agent). Gas halotron tersebut dapat menangani kebakaran kelas A, $\mathrm{B}$ dan $\mathrm{C}$ sehingga dapat digunakan di gedung Kantor Kesehatan Pelabuhan Kelas II Balikpapan.

Menurut Permenakertrans No. 04 tahun 1980, tanda yang menunjukkan APAR berbentuk segitiga sama sisi dengan dasar warna merah, berukuran sisi $35 \mathrm{~cm}$, tinggi huruf $3 \mathrm{~cm}$ berwarna putih dan tanda panah setinggi $7.5 \mathrm{~cm}$ berwarna putih. Sedangkan tanda yang menunjukkan APAR di gedung Kantor Kesehatan Pelabuhan Kelas II Balikpapan berbentuk persegi panjang dengan warna dasar merah, tinggi huruf $5 \mathrm{~cm}$ dengan warna putih dan tanda panah setinggi $7,5 \mathrm{~cm}$ berwarna putih. Tanda APAR yang ada tidak sesuai dengan petunjuk yang diberikan pada Permenakertrans No. 4 tahun 1980 yang seharusnya berbentuk. Namun pemasangannya sudah sesuai dengan peraturan tersebut yaitu 125 $\mathrm{cm}$ dari lantai hingga bawah tanda APAR tersebut dan APAR diletakkan menggantung $10 \mathrm{~cm}$ di bawah tanda tersebut.

\section{SIMPULAN}

Kebijakan mengenai darurat kebakaran di Kantor Kesehatan Pelabuhan Kelas II Balikpapan masih belum ada. Maka diberikan usulan mengenai standar operasional prosedur pada saat terjadi darurat di Kantor Kesehatan Pelabuhan Kelas II Balikpapan. Oleh karena itu, disarankan bagi pengurus untuk dibuatkan suatu kebijakan atau SOP tentang darurat kebakaran yang nantinya dapat digunakan pada saat terjadi darurat kebakaran di gedung Kantor Kesehatan Pelabuhan Kelas II Balikpapan. Perlu dilengkapi fasilitas sarana penyelamat diri yang belum ada di gedung Kantor Kesehatan Pelabuhan Kelas II Balikpapan, seperti membuat jalur evakuasi gedung dan melengkapi sign yang mempermudah penghuni gedung menuju titik kumpul yang telah ditentukan.

Fasilitas pemadam berupa APAR di gedung Kantor Kesehatan Pelabuhan Kelas II Balikpapan sudah ada dan jumlahnya masih sudah sesuai perhitungan menurut Permenakertrans No. 4 Tahun 1980 dan di gedung tersebut masih belum melengkapi sarana penyelamat diri terhadap darurat kebakaran. Telah diberikan usulan mengenai rancangan fasilitas sarana penyelamat diri pada darurat kebakaran (exit route, exit sign dan muster point) di gedung Kantor Kesehatan Pelabuhan Kelas II Balikpapan.

Jumlah APAR yang dibutuhkan di gedung Kantor Kesehatan Pelabuhan Kelas II Balikpapan sebanyak 10 buah dengan jenis dry chemical powder. Telah diberikan juga usulan letak pemasangan APAR beserta tandanya untuk gedung Kantor Kesehatan Pelabuhan Kelas II Balikpapan.

Perlu diadakan pelatihan penggunaan APAR kepada pegawai atau minimal kepada orang yang ditunjuk sebagai petugas pengawas kebakaran. Perlu diadakan simulasi darurat kebakaran di gedung Kantor Kesehatan Pelabuhan Kelas II Balikpapan. Melakukan kegiatan pemeriksaan APAR dan fasilitas 
penyelamat diri secara berkala minimal 6 bulan sekali. Pemeriksaan APAR ini meliputi: pemeriksaan fisik (tabung, selang, nozzle, pengatub, segel, indikator tekanan dan label) dan penempatannya telah sesuai atau belum (Permenakertrans No.4/ MEN/1980).

\section{DAFTAR PUSTAKA}

Angela, T.A. 2006. Studi Kasus: Evaluasi Sistem Penanggulangan Kebakaran PT. Indogravure. Jurnal. Jakarta: FKM Universitas Indonesia.

Dinas Penanggulangan Kebakaran dan Penyelamat Prov. DKI Jakarta. Data Kebakaran Tahun 2014. [Online] Avaliable at: http://www.jakartafire.net/ statistik/index.php? tahunkat $=2014$ [Accessed 31 Maret 2015]

Firdani, L. 2014. Analisis Penerapan Alat Pemadam Api Ringan (APAR) Di PT. X Pekalongan. Jurnal. Semarang: FKM Undip.

Hadhiatma, A. 2015. Penentuan Jalur Evakuasi Bencana Kebakaran di Gedung Menggunakan Algoritma Jalur Jamak. Jurnal. Bali: STMIK STIKOM.

Indrawan, S.M.S. 2013. Sistem Manajemen Pencegahan Kebakaran Gedung Tinggi. Jurnal. Semarang: Asosiasi Ahli K3 Konstruksi Indonesia.

Isnaini, S. 2009. Apar (Alat Pemadam Api Ringan) dan Instalasi Hydrant Sebagai Salah Satu Upaya Pencegahan dan Penanggulangan Kebakaran di Area Pabrik I PT. Petrokimia Gresik. Jurnal. Surakarta: Universitas Sebelas Maret.

Kepmenaker RI No.KEP.186/MEN/1999 Tentang Unit Penanggulangan Kebakaran di Tempat Kerja.
National Fire Protection Association (NFPA) 10 Tahun 2002 tentang Standart Portable for Fire Extinguisher.

Notoatmodjo, S. 2012. Metodologi Penelitian Kesehatan. Jakarta: Rineka Cipta.

Pratama, A. 2016. Perancangan Kebutuhan APAR dan Sarana Penyelamat Diri pada Darurat Kebakaran di Kantor Kesehatan Pelabuhan Kelas II Balikpapan. Skripsi. Surabaya: Universitas Airlangga.

Perda DKI no. 3 Tahun 1992 Tentang Penanggulangan Bahaya Kebakaran dalam Wilayah Khusus Ibukota Jakarta. Jakarta; Setda Pemprov DKI.

Permenakertrans RI NO. 04/MEN/1980 Tentang Syarat-syarat Pemasangan dan Pemeliharaan Alat Pemadam Api Ringan.

Permen PU No. 26/PRT/M/2008 Tentang Persyaratan Teknis Sistem Proteksi Kebakaran pada Bangunan Gedung dan Lingkungan.

Ramli, S. 2010. Petunjuk Praktis Manajemen Kebakaran (Fire Management). Jakarta: Dian Rakyat.

SNI 03-1746-2000 Tentang Tata Cara dan Pemasangan Sarana Jalan Keluar untuk Penyelamatan terhadap Bahaya Kebakaran pada Bangunan Gedung. Indonesia.

SNI 03-3989-2000 Tentang Tata Cara Perencanaan dan Pemasangan Sistem Springkler Otomatik untuk Pencegahan Bahaya Kebakaran pada Bangunan Gedung. Indonesia.

SNI 03-6574-2001 Tentang Tata Cara Perencanaan Pencahayaan Darurat, Tanda Arah dan Sistem Peringatan Bahaya pada Bangunan Gedung. Indonesia. 